NBER WORKING PAPER SERIES

\title{
IMMIGRATION AND PRODUCTION TECHNOLOGY
}

\author{
Ethan G. Lewis \\ Working Paper 18310 \\ http://www.nber.org/papers/w18310 \\ NATIONAL BUREAU OF ECONOMIC RESEARCH \\ 1050 Massachusetts Avenue \\ Cambridge, MA 02138 \\ August 2012
}

This article was written for the Annual Review of Economics. When citing this paper, please use the following: Lewis E. 2012. "Immigration and Production Technology." Annual Review of Econonmics 5: Submitted. DOI: 10.1146/annurev-economics-080612-134132. I especially want to thank David Card and Paul Beaudry for considerable guidance in my research which led to some of the ideas in this article, though many others contributed as well including David Autor, Elizabeth Cascio, Ken Chay, John DiNardo, Mark Doms, Tim Dunne, Christian Dustmann, David Green, Jennifer Hunt, Larry Katz, Giovanni Peri, Steve Raphael and Seth Sanders. Jennifer Hunt and David Green also provided detailed feedback on an earlier draft of this article. All errors herein are my own. The views expressed herein are those of the author and do not necessarily reflect the views of the National Bureau of Economic Research.

NBER working papers are circulated for discussion and comment purposes. They have not been peerreviewed or been subject to the review by the NBER Board of Directors that accompanies official NBER publications.

(C) 2012 by Ethan G. Lewis. All rights reserved. Short sections of text, not to exceed two paragraphs, may be quoted without explicit permission provided that full credit, including $(\mathrm{C}$ notice, is given to the source. 
Immigration and Production Technology

Ethan G. Lewis

NBER Working Paper No. 18310

August 2012

JEL No. J23,J24,J61,O31,O33

\begin{abstract}
Research on the labor market impact of immigration typically relies on a single-good model of production with separable capital. This article discusses theory and evidence that suggest that this standard model is too simple to capture the labor market impact of immigration. A reasonable level of capital-skill complementarity, for which there is considerable support outside research on immigration, alone reduces the relative wage impact of immigration by 40 percent compared to simulations with skill-neutral capital. Other models in which the production structure responds to skill mix changes, including models with endogenous choice of technique, directed technical change, or human capital spillovers, can also imply the impact of immigration is considerably different than in the standard model. This article discusses new research which tries to credibly evaluate such models using immigration-induced variation in skill mix, an approach with further potential, and evidence that immigration impacts innovation and firm formation.
\end{abstract}

Ethan G. Lewis

Department of Economics

Dartmouth College

6106 Rockefeller Hall

Hanover, NH 03755

and NBER

ethan.g.lewis@dartmouth.edu 


\section{Introduction}

Immigrants are a substantial and rising fraction of many countries' populations (e.g, Hanson, 2009), and often arrive in their new country with a different mix of skills than the existing workforce. ${ }^{1}$ As a result, immigration often has a substantial impact on skill ratios in the host country. For example, Table 1 shows 1990s net change in immigrant stock as a proportion the existing workforce by broad education - college/non college -for several developed countries. ${ }^{2}$ The difference in this ratio, shown in column (3), approximates immigration's percentage impact on the college/noncollege ratio. ${ }^{3}$ The U.S. stands out as nearly alone among developed countries in having immigration reduce the skill content of the workforce; more generally, there is quite a bit of variation across countries in this measure. Not shown is the fact that there is also a lot of regional variation within countries: immigrants, for example, tend to cluster into "ethnic enclaves" in the countries where they settle. In the U.S., which is the focus of many of the studies discussed below, a similar measure ranges from -0.12 in Salinas and Anaheim, CA to 0.09 in State College, PA. ${ }^{4}$

Outside of research on immigration, models often allow such skill mix changes to affect the production technology itself: in endogenous growth models, in models of directed technical change, in models of endogenous choice of technique, and in models in which technology and skill are complements. In contrast, despite potentially having a substantive impact on the assessment of immigration's impact on the labor market, studies of the labor market impact of immigration typically do not allow for such impacts, but instead usually model immigration as passively working

\footnotetext{
${ }^{1}$ In this article, I largely assume away any impact of a skill balanced inflow of immigrants and focus on the impact of inflows that affect skill ratios. As we will see below, capital / labor ratios appears to quickly revert to their previous levels in response to shocks. I also assume production is homogenous, and so ignore the role of agglomeration economies. As immigrants disproportionately settle in large metropolitan areas, returns to scale associated with immigration may be small. Another scale effect I ignore is the effect of immigration on the size of the consumer base (see Borjas, 2009).

2 Data are from Docquier et al. (2010).

${ }^{3}$ Letting $S_{I}, S_{N}$ represent, respectively, the quantity of immigrant and native-born skilled labor, and $U_{I}, U_{N}$ unskilled labor, the impact of immigration on the $\ln$ skill ratio is given by $\ln \left(\frac{S_{N}+S_{I}}{U_{N}+U_{I}}\right)-\ln \left(\frac{S_{N}}{U_{N}}\right)=\ln \left(1+S_{I} / S_{N}\right)-\ln \left(1+U_{I} / U_{N}\right) \approx$ $S_{I} / S_{N}-U_{I} / U_{N}$.

4 Computed using 5\% public use 2000 Census of Population using immigrants who arrived in the 1990s.
} 
through a fixed production structure (most often, a single good model with separable capital). Conveniently, the impact of immigration on skill ratios can then be mechanically translated into an impact on wages with a few parameters, for example, as is computed in column (4) of Table 1 assuming a typical value for the college/non-college elasticity of substitution (1.5). ${ }^{5}$ Reduced form estimates of immigration's impact using regional variation that deviate from these mechanical predictions are considered surprising.

This has begun to change. This article reviews recent investigations that allow richer models of production than are typically used to describe immigration's impact. ${ }^{6}$ There are a variety of ways to enrich the production structure to allow for a broader impact of immigration, but this article focuses mainly on two that have considerable empirical support outside immigration research: models of endogenous choice of technique (e.g., Beaudry \& Green 2003, 2005; Caselli \& Coleman 2006) and models of capital-skill complementarity (e.g., Krusell et al. 2000). I will also review research examining the effect of immigration on growth related outcomes, such as productivity and patenting. Finally, I will describe recent empirical research on the impact of immigration on entrepreneurship and the role firm formation plays in absorbing immigrant inflows.

A key implication of this new research is that the old, simple view that the only labor market impact of immigration is to drive down the relative wages of "similar" native-born workers in a predictable, mechanical way may be a highly incomplete description of the long-run impact of immigration. There is another way to look at this, too. Though many of these richer models have compelling features, the existing empirical support for them is often largely based on cross-country or time series correlations, leaving open the possibility that it is spurious. Researchers can and

\footnotetext{
5 That is, the percentage change in the college ("skilled") relative wage is computed as $\% \Delta\left(W^{S} / W^{U}\right)=-\frac{1}{\varepsilon} \% \Delta(S / U)$, where $\varepsilon=1.5$ is the elasticity and $\% \Delta(S / U)$ is the change in the skill ratio induced by immigration (column 3 ). ${ }^{6}$ Some semantics should be cleared up: if immigration impacts production technology in some way, one could always create a richer "fixed" model of production that encompasses this "impact." Another way to put what is being argued, then, is that the models of production typically used in studies of the labor market impact of immigration may be too simple to capture immigration's impact.
} 
have applied well-developed strategies for identifying the impact of immigration on wages to help more credibly evaluate these richer models of production.

\section{Theories}

\section{The Standard Model}

Consider first the single good model of the economy that has become standard in studies of the labor market impact of immigration. For simplicity, consider two labor types, $\mathrm{S}$ and $\mathrm{U}$ for skilled and unskilled, respectively, and a single type of capital, K. A standard approach is to write down an aggregate production function which is separable in capital and labor:

(1) $Q=g(K, f(S, U))$

More generally, one might have several labor types in the function f. Immigration is modeled as affecting the relative quantities of the different labor types, in some cases with a very modest degree of imperfect substitutability with natives of the same "type."7 This is the modeling approach taken by a large number of studies, including ones which disagree substantially about the impact of immigration on the labor market, including Card(2001), Borjas(2003), Ottaviano \& Peri (2012) to

\footnotetext{
${ }^{7}$ Specifically, it is recently typical to add an inner CES nest with $S \equiv\left(S_{I}^{\rho}+S_{N}^{\rho}\right)^{1 / \rho}$ and $U \equiv\left(U_{I}^{\rho}+U_{N}^{\rho}\right)^{1 / \rho}$, where $S_{I}$ and $S_{N}$ are immigrant and native, respectively, skilled labor and $U_{I}$ and $U_{N}$ are immigrant and native unskilled labor. Although there was some fractious debate on this point (see Ottaviano \& Peri 2006, and Borjas et al. 2008), the literature has now settled down on the view that $\rho$ may be something slightly less than one, i.e., that there is a very modest degree of imperfect substitutability. In a cross-metro area analysis in the 1980-2000 U.S. Censuses, Card (2009) estimates $\rho$ 's in the range of 0.95-0.98. Ottaviano \& Peri's (2012) aggregate estimates are in a similar range.
} 
name a few. ${ }^{8}$ For the purposes of this discussion, I will simply assume that $\mathrm{g}$ is homogenous of degree one; most recent studies specify g and $\mathrm{f}$ together as a nested constant elasticity of substitution (CES) production function, often with a Cobb-Douglass outer nest.

Specifying capital as separable in production essentially makes it ignorable in estimation. ${ }^{9}$ In a perfectly competitive labor market, (1) conveniently implies relative wages are independent of capital:
(2) $\ln \frac{W^{S}}{W^{U}}=\ln \frac{f_{1}}{f_{2}}$

For example, it has become common to define "S" as college educated labor and "U" non-college labor, and with a nested CES structure (2) would reduce to $\ln \frac{W^{S}}{W^{U}}=-\frac{1}{\varepsilon} \ln \frac{S}{U^{U}}$, where $\varepsilon$ is the elasticity of substitution between college and non-college labor (i.e., $f(S, U)=\left(S^{\frac{\varepsilon-1}{\varepsilon}}+U^{\frac{\varepsilon-1}{\varepsilon}}\right)^{\frac{\varepsilon}{\varepsilon-1}}$ ). Taking a "consensus" value of $\varepsilon$ of about 1.5 for this skill pair (e.g., Hamermesh, 1993; specific estimates discussed below) one can translate the skill mix changes in Table 1, column (3) into estimated relative wage impacts, shown in column (4).

In addition to making capital ignorable in estimating relative wage impacts, capital separability implies capital's share in output is invariant to immigration shocks in the long run. This is the most obvious if $g$ is Cobb-Douglass, as is commonly assumed. ${ }^{10}$ However, increases in S/U do increase

\footnotetext{
${ }^{8}$ Interestingly, earlier studies of the labor market impact of immigration, including Altonji \& Card(1991), Grossman(1982), and Borjas(1987), had richer production structures.

${ }_{9}^{9}$ With one exception: capital affects the short-run impact of immigration on absolute wages. As will be discussed below, though, the "short run" may have little empirical relevance to the impact of immigration.

${ }_{10}$ More generally, $r K / Q=\frac{r g_{K}^{-1}(r, 1)}{g\left(g_{K}^{-1}(r, 1), 1\right)}$ is only a function of $\mathrm{r}$, the rental rate of capital (where $g_{K}^{-1}(r, 1)$ is the solution to $g_{K}(K, 1)=r$ for $\left.\mathrm{K}\right)$, not skill ratios.
} 
capital-labor ratios, a point which I will return to in distinguishing this model from one featuring capital-skill complementarity (next section). ${ }^{11}$

Moving towards this point, one potential problem with this standard approach is that it is at odds with substantial evidence, going back to at least Griliches (1969), that capital and skill are relative complements. Also, a large literature argues that computing technologies, in particular, are complementarity with skilled labor. This is supported with evidence that the rapid decline in their prices in recent decades has pushed up relative demand for skilled labor (e.g., Katz \& Murphy 1992; Krueger 1993; Autor et al. 1998; Autor et al. 2003; Autor et al. 2006, 2008), so called "skill-biased technical change" (SBTC). So I now turn to models that include capital-skill complementarity.

\section{Capital-Skill Complementarity}

Any production structure in which $\partial \ln \frac{W^{S}}{W^{U}} / \partial \ln K>0$, that is, in which capital and skilled labor are "q-complements" relative to capital and unskilled labor $\left(\partial \ln W^{S} / \partial \ln K>\partial \ln W^{U} / \partial \ln K\right)$, is sufficient for what I will call capital-skill complementarity. ${ }^{12}$ This relative definition is critical. In the standard model above, both $\mathrm{S}$ and $\mathrm{U}$ are q-complementary with capital, but $\mathrm{S}$ is not qcomplementarity with capital relative to U. For tractability, researchers since at least Goldin \& Katz (1998) have mostly relied on a CES production function, for example:

(3) $Q=\left[\alpha\left(U^{\delta}+K^{\delta}\right)^{\mu / \delta}+(1-\alpha) S^{\mu}\right]^{1 / \mu}$

Under (3), short-run relative wages can be expressed as:

\footnotetext{
${ }^{11}$ Rewriting the first order condition for capital as $g_{K}\left(\frac{K / L}{f(S, U) / L}, 1\right)=r$, where $L=S+U$, an immigration-induced increase in $\mathrm{S} / \mathrm{U}$ will raise $f(S, U) / L$ and must therefore also raise $K / L$.

12 It is also equivalent to say capital has a greater elasticity of complementarity (Hamermesh, 1993) with skilled than with unskilled labor. See appendix.
} 
(4) $\ln \frac{W^{S}}{W^{U}}=\ln \frac{(1-\alpha)}{\alpha}+(1-\mu / \delta) \ln \left(1+\left[\frac{K}{U}\right]^{\delta}\right)+(\mu-1) \ln \left(\frac{S}{U}\right)$

(4) shows that capital complements skill, $\partial \ln \frac{W^{S}}{W^{U}} / \partial \ln K>0$, as long as $\delta>\mu .^{13}$

(4) also seems to imply that the impact of a change in $S / U$ on relative wages might not be that different than if the substitution elasticity between $\mathrm{S}$ and $\mathrm{U}$ was $\varepsilon=(1-\mu)^{-1}$ and capital was skill neutral. However, (4) is not a long-run condition for wages. Under elastic capital supply, models (1) and (3) predict very different impacts of an immigration-induced increase in S/U. In particular:

- Unlike (1), (3) implies that an increase in S/U drives up capital's share in output, $\partial \ln s_{K} / \partial \ln (S / U)>0$, where $s_{K}=r K / Q$ is capital's share. The reverse is also true: $\partial \ln s_{K} / \partial \ln (S / U)>0$ implies capital-skill complementarity, which is the basis for Lewis (2011a), discussed below. This applies to any concave, homogenous production function, not just (3). (See Appendix.)

- Relative wages are less responsive to skill mix changes in the long run (capital elastic) than in the short run (capital fixed). Again, this is a general result.

In the case of (3), one can approximate the long-run elasticity of relative wages to changes in skill mix by substituting the first order condition for K into (4) (both log linearized), which produces

$\frac{\partial \ln W^{S} / W^{U}}{\partial \ln S / U} \approx \frac{(\delta-\mu)(1-\mu) s_{S} s_{K}}{(\delta-\mu) s_{K} s_{S}+(1-\delta)\left(1-s_{S}\right)\left(1-s_{K}\right)}+(\mu-1)$

where $s_{S}=W^{S} S / Q$ is skilled labor's share. Note that $\frac{(\delta-\mu)(1-\mu) s_{S} s_{K}}{(\delta-\mu) s_{K} s_{S}+(1-\delta)\left(1-s_{S}\right)\left(1-s_{K}\right)}+(\mu-1)>$ $(\mu-1)$, the short-run elasticity. In the short run, an immigration-induced increase in skilled relative employment lowers skilled relative wages per (4). In the long run, the same skill shock raises capital's share in output - in the case of (3) by $\frac{\partial \ln s_{K}}{\partial \ln S / U} \approx \frac{(\delta-\mu)\left(1-s_{S}-s_{K}\right) s_{S}}{(\delta-\mu) s_{K} s_{S}+(1-\delta)\left(1-s_{S}\right)\left(1-s_{K}\right)}>0$ - and

13 It is also assumed that $\delta, \mu \leq 1$. 
skilled relative wages, mitigating the short-term impact. This is driven by the fact that unskilled labor is substitutable for a factor whose long-run price is fixed.

In contrast, when capital is separable and therefore skill neutral, the short- and long-run impacts of skill mix changes on relative wages are the same (previous section). To get a sense of the magnitude of this distinction, Table 2 runs simulations of (3). The upper panel assumes a CobbDouglass outer nest $\left(\mu=0\right.$, so $\left.Q=\left(U^{\delta}+K^{\delta}\right)^{\alpha / \delta} S^{1-\alpha}\right)$, following Stokey (1996), Lewis (2011a), and Autor et al. (2003). ${ }^{14}$ Start with the parameter values assumed in Stokey $(1996)(\delta=0.5, \alpha=0.38)$ and assume $s_{K}=0.3$. Row (2) shows this implies $\partial \ln \frac{W^{S}}{W^{U}} / \partial \ln \frac{S}{U}=-0.59$, that is, more than 40 percent smaller in magnitude than predicted in the benchmark capital-neutral case $(-1.00$, row 1$)$. Row (3) shows that Lewis's estimate of the response of capital to changes in skill mix - Lewis uses high school graduates/dropout - are consistent with Stokey's assumption that $\delta=0.5 .{ }^{15}$ It also shows that wage responses are not sensitive to perturbations to share changes $\left(\mathrm{S}_{\mathrm{K}}\right.$ is lower and $\mathrm{S}_{\mathrm{S}}$ higher since Lewis only examined equipment capital.) The simulated wage impacts are more sensitive to the value of $\delta$, especially at the extremes. If $\delta$ close to one, the long run impact of immigration on relative wages is negligible. The lower panel of Table 2 shows estimates assuming $\mu=0.33$, that is, with a short-run elasticity of substitution between skill types of $(1-0.33)^{-1} \approx$ 1.5 , about the "consensus" value between college and non-college workers and what was used in simulations in Table 1, column (4). This also exhibits considerably smaller long-run wage responses to skill mix under complementarity (rows 8-10) than under neutrality (row 7), again 40 percent smaller using Lewis's estimates. In summary, Table 2 shows that relative wage impacts simulated using a capital-neutral CES model (once called the "factor proportions" approach) may

\footnotetext{
14 In Stokey (1996), “U” represented physical labor input supplied by unskilled workers, and "S" represents effective units of human capital supplied by all workers. In Lewis (2011a), U is dropouts and S high school completers, and he adds another CES nest to (3), with another type of labor.

${ }_{15}$ Rows (3) and (8) solve the expression above for $\frac{\partial \ln s_{K}}{\partial \ln S / U}$ for $\delta$ given Lewis's estimate that $\frac{\partial \ln s_{K}}{\partial \ln S / U}=0.168$ and the other parameter values, and then computes wage impacts. Lewis's estimates are further discussed in the empirical section.
} 
substantially overstate the long-run impact of immigration. ${ }^{16}$ To be fair to such studies, which include Ottaviano \& Peri (2012) and Borjas et al. (1997), estimates of the elasticity of substitution between labor types generally come from estimates of the reduced form relationships between relative wages and skill mix, which could include some of the effect of capital adjustments.

Importantly, for most purposes the "long run" may be the most relevant for the study of immigration's impact on the labor market. Immigration is typically an ongoing flow, not a one-time spike, and capital stocks appear to adjust rather quickly, as evidenced by the fact that they appear to revert to trend within a few years of shocks in U.S. data (see, e.g., Ottaviano \& Peri 2006). Indeed, direct evidence on the speed of adjustment of wages to immigration shocks suggests full adjustment occurs within a couple of years, if not sooner (e.g., Cohen-Goldner \& Paserman 2011; Card 1990). ${ }^{17}$ In particular, in assessing the impact of immigration with something like decadal frequency, as is frequently done in U.S. data, treating capital stocks as flexible seems most appropriate. Henceforth, I will therefore consider mainly long run equilibria.

\section{Choice of Technique Models}

Some models allow producers to choose among several production functions, not just one. For example, in Beaudry \& Green $(2003,2005)$ the arrival of computers represents a "technological revolution" (Caselli 1999) essentially modeled as the arrival of a more skill-intensive technology. In

\footnotetext{
16 In contrast to the results in Table 2, I find that simulations using Krusell et al.'s (2000) production function estimates (of (3), but with S and U switched) imply very little sensitivity of relative wages to the adjustment of capital. However, their estimates also imply very little response of capital-output ratios to changes in skill mix (they estimate with aggregate data, in which capital-output ratios are stable), showing again the two responses go hand-in-hand. Put another way, their production function exhibits very little of what I define as capital-skill complementarity.

17 The short run effects may have some relevance to the immediate aftermath to an event like the Mariel boatlift or the refugee flows after Hurricane Mitch (Kugler \& Yuksel 2008). On the other hand, Card (1990) finds no evidence of impacts even in the immediate aftermath of the boatlift. Other recent examples of studies of immigration's short-run immigration dynamics include Barcellos (2010) and Wozniak \& Murray (2012).
} 
this and similar models, producers' optimal choice of technology is affected by skill mix, and so the response of technology to immigration may mediate immigration's ultimate labor market impact.

To see this, consider a simplified version of Beaudry \& Green's model depicted in Figure 1 and used in Beaudry et al. (2010) (hereafter, BDL). It depicts unit isoquants of a "traditional" and a "modern" technique which is more skill intensive. In this classic "two sector" model, just like an open economy 2 x 2 case of Heckscher-Ohlin model, wages are insensitive to skill mix changes (including those induced by immigration) as long as the economy's skill mix remains within the "cone of diversification," that is, inside the two expansion path lines; relative wages are given by the slope of the dashed tangency line. ${ }^{18}$ The impact of skilled immigration in this model is instead to shift production to the modern technique. If the modern technique is more capital intensive, this would also show up as reduced capital intensity. Thus, the empirical implications of this model can overlap with capital-skill complementarity.

More generally, Caselli \& Coleman (2006) consider a model in which producers choose among a continuum of production techniques of differing skill intensities. Consider a version of their setup, the CES production function:

(5) $Q=A K^{\alpha}\left[(\beta S)^{\sigma}+([1-\beta] U)^{\sigma}\right]^{(1-\alpha) / \sigma}$

Where $\beta \in(0,1)$ is share parameter that producers choose and A is a TFP parameter, whose value is, for now, exogenous. Relative wages satisfy:

(6) $\ln \frac{W_{S}}{W_{U}}=\sigma \ln \frac{\beta}{1-\beta}+(\sigma-1) \ln \frac{S}{U}$

\footnotetext{
18 In the open economy interpretation of this figure, wages are insensitive to skill mix changes because the local economy is a price taker on the large world market (and so shifts in product mix can occur without affecting any prices). In the Beaudry-Green interpretation of the model it is because the output of the two techniques is assumed to perfectly substitutable.
} 
BDL and Beaudry \& Green $(2003,2005)$ suppose producers choose between exactly two values of $\beta$, with $\beta^{\text {Modern }}>\beta^{\text {Traditional }}$. In Caselli \& Coleman (2006), producers choose among techniques from the frontier $\beta^{\omega}+\rho(1-\beta)^{\omega} \leq B$, where $\omega, \rho$, and $B$ are exogenous positive parameters, with $\omega>\sigma /(1-\sigma)$ assumed in order to obtain an interior solution. In both continuous and discrete cases, an immigration-induced increase in S/U induces producers to shift to a technique with a larger $\beta$, implying that wages respond less negatively to skill mix changes than when $\beta$ is fixed. ${ }^{19}$

A related set of models suggests that skill mix affects the nature of innovations in production technology, models of so-called "directed technical change" (Acemoglu 1998, 2002). If immigration increases the size of the skilled workforce, it increases inventors' potential monopoly profits from inventions that raise skilled productivity, thus giving an incentive to "direct" innovation towards skilled workers. Like in models of endogenous technical choice, in these models the relative demand curve is less downward sloping in the long run that in the short run. Unique to models of directed technical change, however, is the possibility that long run relative demand curves slope upwards. Acemoglu proposes this as an explanation for why relative skill demand has outpaced supply over the past few decades, leading to increased wage inequality. ${ }^{20}$

\section{Multisector Models}

The standard approach of representing the economy as a single good aggregate production function may also be inadequate. ${ }^{21}$ In open economy models with multiple industries, the wage impact of an

\footnotetext{
${ }^{19}$ In particular, after the adjustment of $\beta, \partial \ln \frac{W_{S}}{W_{U}} / \partial \ln \frac{S}{U}=\sigma-1+\sigma^{2} /(\omega-\sigma)>\sigma-1$. Interestingly, the value of $\sigma$ Caselli and Coleman choose, 0.286 , and their estimate of $\omega=0.41$ together imply very little long-response of relative wages to skill mix.

${ }^{20}$ Beaudry and Green (2005), trying to explain the same facts, obtain short-run upward sloping relative demand from the assumptions that the modern technique is more skill- and less capital-intensive than the traditional one but has higher capital-labor ratios.

21 Card (2009) cites Fisher (1969) for the result that there is little theoretical reason to expect different industries to aggregate to a single production function and Fisher et al. (1977) for the result that in practice, simulated aggregation of CES industries with different elasticities of substitution appear to behave as a single aggregate CES production function.
} 
immigration-induced shift in skill mix can be mitigated by a shift in the composition of industries, a channel that is ruled out by a single good model. (Even in a closed economy, shifts in industry mix can help absorb immigrant inflows, if immigrants are concentrated in sectors where demand is elastic, such as personal services. See Cortes 2008.) The simplest small, open economy model is isomorphic to choice of technique models described above. Recall that Figure 1 could alternatively represent a two-sector small, open economy model - and modern and traditional "techniques" could alternatively represent goods of differing factor intensities - with the identical predication that wages are insensitive to skill mix changes inside the cone of diversification.

More generally, it is well known that as long as there are more "industries" (really products of differing factor intensities) than "factors of production" this factor price insensitivity result will hold. ${ }^{22}$ Like in the $2 \times 2$ case in Figure 1, instead of affecting relative wages, a relatively skilled immigrant influx is absorbed by so-called "Rybczynsi effects," shifting the output mix towards skillintensive products. This is possible because there is infinitely elastic world demand for the different products, or, more simply, the shifts in output mix in this small economy have no effect on product prices. ${ }^{23}$

In addition to being similar theoretically, choice of technique and open economy models are confounded empirically: both can lead to factor price insensitivity. To distinguish them, one therefore must examine the response of product mix. To see this more explicitly, let $i$ indexes labor types (say, S or U in the simplified frameworks we have been using) and $j$ index products. Each product has a cost function $c^{j}(W)$, where $\mathrm{W}$ is the vector of wages for each skill type. Shephard's

\footnotetext{
22 This can hold even if not all industries are traded, as long as there are more traded industries than factors of production, and the ratio of marginal to average propensity to consume for the non-traded good does not exceed the inverse of capital's share of income (Ethier 1972). Homothetic preferences are sufficient for the latter.

23 More recent trade models feature potentially imperfectly substitutable "local varieties" of different goods. Ciccone \& Peri (2011) review how shifts in skill mix are absorbed in this more general framework.
} 
Lemma implies $N_{i}=\sum_{j} Q_{j} c_{i}^{j}(W)$, where $N_{i}$ represents total employment of factor $i, Q_{j}$ represents the output of product $j$, and $c_{i}^{j}(W)$ is the $i^{\text {th }}$ derivative of the cost function. In log differential form:

(7) $d \ln N_{i}=\sum_{j} \varphi_{i j} d \ln Q_{j}+\sum_{j} \varphi_{i j} d \ln c_{i}^{j}$

Where $\varphi_{i j}=N_{i j} / N_{i}$ is the share of $i$-type workers in $j$. (7) decomposes growth in type-i labor demand into changes in product mix (the first term) and changes in factor intensities within product (second term). In the extreme, if factor price equalization fully holds, the second term is zero and all changes in skill mix are entirely absorbed by changes in product mix, $d \ln N_{i}=$ $\sum_{j} \varphi_{i j} d \ln Q_{j} .{ }^{24}$ In another extreme, immigration-induced skill mix changes are absorbed by changes in production technique, and the second term is large (that is, despite the fact that there is little response of wages.) Papers which have evaluated this model create empirical versions of (7) and ask how much skill mix changes are absorbed "between" rather than "within" industries (potentially imperfect proxies for products - more below).

\section{Models with Human Capital Externalities}

Recently, studies of immigration have allowed for Marshallian human capital externalities.

Adopting the framework from Moretti (2004a, 2004b), Peri (2011), and Docquier et al. (2010), relax the assumption that $A$ in (5) is exogenous and instead model it as: 25

(8) $\ln A=\ln A_{0}+\lambda \frac{S}{S+U}$

${ }^{24}$ Since $d \ln c_{i}^{j}=\sum_{k} \frac{c_{i k}^{j}}{c_{i}^{j}} d \ln w_{k}$, but $d \ln w_{k}=0 \forall k$ under factor price equalization.

25 In both Moretti and in Peri, this specification is for $S=$ college and $U$ = non-college workers. Iranzo and Peri (2009) generalize this to allow for different spillovers from average education among college and non-college workers. 
If $\lambda>0$, there are human capital spillovers. Adding this feature to production changes the impact on wage levels, but not relative wages. As Moretti described it, an increase in skill share has a smaller negative impact on skilled wage levels than is implied by the elasticity of substitution (between $\mathrm{S}$ and $\mathrm{U}$ ). This is because the supply effect is partially offset by the human capital spillover. Note that this equivalently implies that a less-skilled immigration inflow would reduce the wages of less-skilled workers by more than is implied by the elasticity of substitution.

\section{Evidence}

With the exception of the model of human capital spillovers, all of the alternatives to the standard model have a prediction in common: the long-run impact of immigration on the wage structure may be less than what is implied by a comparable single-good capital-neutral production structure. So what does the evidence say?

Until recently, there was a strong prima facie case that at least one of the "non-standard" (including open-economy) models applied: "area studies" - that is, studies which used variation across regions in the quantity of immigration - consistently found very little impact of immigration on wages or employment outcomes (Longhi et al. 2005, 2008; also earlier reviews by Borjas 1994, and Friedberg \& Hunt, 1995). In particular, the estimates were smaller than what would be predicted by the standard model using other (often derived from more aggregate variation) estimates of the elasticity of substitution between workers of different skill levels, such as Borjas (2003), Ottaviano and Peri (2012), or studies reviewed in Hammermesh (1993).

On the other hand, Card (2009) has prominently argued that, properly specified, the labor market impact of immigration estimated across areas does replicate other, aggregate estimates of the elasticity of substitution. In particular, he argues (and provides wage evidence) that college 
graduates and non- graduates are imperfectly substitutable, but high school dropouts and graduates are perfect substitutes and should be lumped together (with an adjustment for unit efficiency differences). ${ }^{26}$ Responding to criticism that the area approach is also biased towards zero by differences in relative demand correlated with immigrant inflows (e.g., Borjas 1994), or that natives offset the impact of immigration on skill mix through intercity migration (e.g., Borjas 2006), Card also argues that the area approach requires a valid instrumental variable. ${ }^{27}$ Card (2009) uses what has become a standard "ethnic enclave" instrument for predicted changes in skill mix: essentially, predicting changes in skill mix by apportioning aggregate immigrant arrivals, by country of origin, to regions based on the lagged proportions of immigrants from that country in that region. The instrument thus exploits the persistent regional patterns of immigrant flows by origin (e.g., the tendency of Middle Eastern immigrants to settle in Detroit) which is argued to be driven by family reunification or a preference for a culturally familiar environment, rather than labor demand conditions. ${ }^{28}$

Applying this instrumental variables approach to a panel of 124 metro areas constructed from 1980-2000 U.S. Censuses data, Card's (2009) estimates elasticities of substitution between college and non-college workers between 2.44 and 3.85 (Table 5). These estimates are only a bit larger than estimates obtained from aggregate U.S. variation, including Katz \& Murphy's (1992) estimate of 1.41, and Goldin \& Katz's (2008) estimates which range from 1.62 to $1.84 .{ }^{29}$

Does this mean there is no need for anything beyond the standard model? Perhaps. But the debate may not be entirely over. Dustmann \& Glitz (2012), for example, find that wages in the German

${ }^{26}$ Goldin \& Katz (2008), Lewis (2011a), and Ottaviano \& Peri (2012) find some evidence of imperfect substitutability between dropouts and graduates, albeit with a much larger elasticity than between college graduates and non-graduates. 27 In constrast with Borjas (2006), most studies find little evidence that native outmigration "undoes" the local impact of immigration on skill mix (e.g., Card 2001). Peri \& Sparber (2011) argue that Borjas's (2006) specification is biased towards finding a migratory response.

28 The idea of exploiting the fact that immigrants follow other immigrants to similar locations as the basis of an instrumental variables strategy originates with Altonji \& Card (1991).

${ }^{29}$ Although the Card (2009) estimates are slightly larger, both sets of estimates have standard errors, and in light of the longer time frame for the Card estimates (decadal) than the latter (closer to annual variation), these sets of estimates could be entirely consistent. 
traded sector are unresponsive to immigration-driven skill mix shocks, which is inconsistent with the standard model. In addition, even if reduced form estimates of immigration's impact on wages match simple calibrations from the standard model, it does not necessarily imply that the model is correct, as different models can predict roughly the same reduced form elasticity between skill types (for example, see Table 2). Some immigration studies have also attempted to directly look for evidence of the models described above. I consider each in turn.

\section{Capital-Skill Complementarity}

Evidence for capital-skill complementarity goes back to at least Griliches (1969), and more recently it has been evaluated in papers on SBTC. ${ }^{30}$ Recent studies have also looked for evidence of it using immigration-induced variation in skill mix. These studies take advantage of the fact, as was described in the theory section above, that capital-skill complementarity is present if and only if capital output ratios respond positively to exogenous increases in skill ratios. The advantage of this approach, relative to the typical SBTC approach of studying how capital adoption affects measures of relative skill demand, is the potential for finding valid exogenous variation (using, e.g., the "ethnic enclave" style instrument described above). Finding credible exogenous variation is much more challenging when the independent variable is some type of capital adoption variable.

One example of this new approach is Lewis (2011a). The study merges data on equipment capital and output from Censuses of Manufactures, data on automation equipment from the 1988 and 1993 Surveys of Manufacturing Technology, and data on skill mix from U.S. Censuses and Current Population Surveys, all aggregated to the metropolitan area level. Lewis finds, consistent with capital-skill complementarity, immigration-induced increases in high school dropouts per high school graduate in a metropolitan area are associated with significantly decreased use of

\footnotetext{
30 See also Hamermesh (1993).
} 
automation equipment and with decreased equipment-output ratios more generally, even within four-digit manufacturing sectors. Lewis's estimates are applied in rows (3) and (8) of Table 2. One shortcoming of Lewis (2011a) is that it did not assess complementarity between capital and college-level workers, the complementarity that has been emphasized by research on SBTC.

Peri (2012) provides some initial evidence on this front. He takes a reduced form approach, examining the relationship between immigration and the growth in the components of a loglinearized version of (5) using cross (U.S.)-state variation over time (decennial Census data). This analysis includes the examination of the relationship between capital-output ratios and immigration. He finds that immigration is associated with a significant decline in the share of a state's workers who are college educated, but not with a significant decline in capital-output ratios, even when using an instrumental variables approach similar to Card (2009). Thus, he finds no evidence of capital-college complementarity. On the other hand, Peri did not have data on capital stocks by U.S. state, but instead imputed state-level capital stocks using industry level data crossed with measures of state-level industry mix. Peri thus only estimates immigration's impact on changes in the capital output ratio that occur through its impact on industry mix, which has generally found to be small (see below). In Lewis (2011a), the response of capital stocks was within industry.

In a metro area level analysis, Doms \& Lewis (2006) find that immigration-induced increases in college share are associated with adoption of more computers per worker between 1990 and 2000. However, as was pointed out in the theory section above, this alone does not prove that there is a complementarity between college educated workers and computers: such a positive association would be expected in the capital-neutral model as well. Although I single out Doms \& Lewis for criticism on this front because they use immigration-based variation, it is not the only SBTC paper 
which does not distinguish between the response of capital-output ratios (which helps identify capital-skill complementarity) and capital-labor ratios (which does not necessarily). ${ }^{31}$

In light of the fact that there is some empirical support for capital-skill complementarity, that immigration variation has been underexploited in its study, and that reasonable values of complementarity imply that the wage impacts of immigration are, perhaps 40 percent smaller than predicted by elasticities of substitution between skill types (Table 2), it seems appropriate for future studies of the labor market impact of immigration to allow for an impact on capital stocks. Although this is easier said than done - detailed data on capital stocks at a regional level tend not to be publicly available -feasible approaches could include:

- Using tabulations of U.S. agriculture, manufacturing, and construction censuses. These, (especially historically) do contain some information on capital or investment. Below I review some of the historical U.S. evidence that uses these data.

- Examining data from different countries, where capital stock data may be easier to obtain, or across countries.

Longer term it would be nice to develop more detailed regional measures of capital stock using confidential data. ${ }^{32}$ In the near term, though, the lack of easily accessible data on capital stocks will mean that the standard model, in which capital is ignorable, will continue to have a lot of practical appeal. So another approach would be to use simulation based approaches, like Table 2, to determine how sensitive assessments of the labor market impact of immigration are to complementarity, or to help more accurately interpret reduced form estimates.

\footnotetext{
${ }^{31}$ A common approach in papers on SBTC is to regress, using variation across industries, measures of the skill intensity of labor mix on measures of computer- or capital-labor ratios and interpret positive coefficients as support for complementarity. Interestingly, some of the earlier SBTC studies are much more careful to examine capital-output ratios where the data are available (e.g., Autor et al. 1998).

32 Some data are available, but not widely known: Dan Wilson and Robert Chirinko used perpetual inventory methods to convert state-level tabulations of capital investment into a state-level panel of capital stocks for manufacturing, covering 1962-2006. See http://www.frbsf.org/economics/economists/staff.php?dwilson.
} 


\section{Choice of Technique and Open Economy Models}

Peri (2012) examines directly whether immigration has affected the skill share parameter, $\beta$, in (5) using U.S. Census-derived data on wages for college ("S") and non-college ("U") workers. As (6) makes clear, the impact of immigration on $\beta$ cannot be separately identified from the direct effect of immigration-induced changes in skill mix on wages. To get around this, Peri imposes an elasticity between skill types, which he sets at 1.75 in the main. ${ }^{33}$ With this, he finds a very strong effect of immigration on $\beta$ : in his IV estimates, a one percentage point in immigrant workforce share is associated with a one percent decline in $\beta$. Since, according to his estimates, immigration is associated with a similar magnitude decline in college share, (6) shows that the response of $\ln \frac{\beta}{1-\beta}$ offsets most of the direct effect of changes in skill mix on wages.

This result reveals the weakness of this identification strategy, though: it is essentially identified off deviations in the response of wages to supply shocks from "calibrated" estimate (imposing an elasticity of substitution). ${ }^{34}$ As we have seen, there are other explanations for a smaller than expected response of relative wages to immigration shocks, so wage evidence alone cannot be definitive support for a choice of technique model. In addition, as many have pointed out (e.g., Borjas 1994), cross-regional studies of the effects of immigration may be biased towards zero by relative demand shocks correlated with immigrant inflows, or, more generally, skill mix may be endogenous. Since Peri (2012) uses the standard "ethnic enclave" type of instrumental variables strategy, such concerns may be limited in this case, but this cannot be said of Caselli \& Coleman (2006) who have no instruments. ${ }^{35}$

\footnotetext{
33 That is, $\sigma$ in (5) satisifies $1.75=(1-\sigma)^{-1}$. (A point of potential confusion: in the way Peri parameterized production, which is equivalent to (5), $\sigma$ itself represents the elasticity of substitution). Note that this is the same approach Caselli \& Coleman (2006) take with cross-country data, where they impose $(1-\sigma)^{-1}=1.4$.

34 Indeed, Peri is transparent about the fact that his estimates are sensitive to the choice of $\sigma$.

35 Disappointingly, neither study actually shows reduced form estimates of the response of relative wages, which would have been a more transparent approach.
} 
Lewis (2011a) considers the choice of technique model in BDL and Figure 1, but rules this out after finding non-zero response of relative wages to relative supply. However, while this does rule out the specific choice of technique model he considers, it does not rule out more general choice of technique frameworks (Beaudry \& Green 2003, 2005; Caselli \& Coleman, 2006).

An important measurement issue in distinguishing choice of technique models from open economy models, shown in (7), is that can both lead to attenuated responses of wages to skill mix changes. What distinguishes the two is that, in the latter, the economy responds to skill mix changes with shifts in product mix, while in the former it responds with shifts in production technique for a given product. On this front, studies including Lewis (2003), Card \& Lewis (2007), and Gonzales \& Ortega (2011) use employment data by industry to proxy for product mix, the first term in (7), and skill ratios within industry to proxy for production technique, the second term. They then regress each component on skill mix changes, instrumented with immigration instruments. These studies find very little of immigration-induced shifts in skill mix - typically less than 10 percent - are accounted for by shifts in industry mix, leaving most to within industry changes in skill intensity. ${ }^{36}$

While this appears to be strong evidence against the importance of open-economy adjustments, trade economists often argue that industry-level analyses suffer from aggregation bias, obscuring shifts in product mix that occur at the subindustry level (e.g., Schott 2004). To address this, Dustmann \& Glitz (2012) (DG) use German data in which it is possible to measure skill intensity at the firm level. Comparing across German regions between 1985 and 1995, they generalize from (7) and decompose immigration induced changes in education mix into within and between firm (rather than industry) and net entry components.37 They find that "within (permanent) firm"

\footnotetext{
36 One exception is Lewis (2004), who finds some initial support for the idea that the Mariel boatlift led Miami's output mix to shift away from skill intensive manufacturing industries relative to comparison cities. However, the results are not robust to the choice of comparison group.

37 Like the other studies, they use employment as a proxy for output.
} 
changes in skill intensity account for 71 percent of immigration-induced skill mix changes. ${ }^{38}$ The remainder is split evenly between shifts in employment across permanent firms, what they call "scale effects," and net entry. The net entry effect they then further split into changes in factor intensity and scale and show much is also due to changes in factor intensity. They separately show that an industry-level analysis would attribute less than a firm-level analysis to scale effects supporting the aggregation bias view - though the difference is not very large.

Although firms are not really the same thing as "products" -some shifts in employment across firms might be due to shifts in production methods rather than product mix (something the authors acknowledge) - it seems plausible that they are closer to products than industries are. In light of this, it is stunning how just how responsive skill intensity within firm is to aggregate skill mix changes - within permanent firms DG find that changes in skill ratios are 82 percent as large as immigration-induced changes in the market as a whole - when, recall, relative factor prices are not changing in response to the same immigration shocks. This reinforces the view that some type of "choice of technique" model may indeed operate in the labor market.

To summarize, the three key points for empirical research on "choice of technique" models are:

1. Wage evidence alone is not adequate to establish support for a choice of technique model. As this article describes, there are many models of the labor market which would allow the impact of immigration on the wage structure to be smaller than what is predicted by established elasticities of substitution between labor types.

2. However, it is important to establish that there is a small wage impact before turning to direct evidence on choice of technique.

In short, wage evidence is necessary but not sufficient, and finally:

\footnotetext{
38 I refer to their IV estimates, which employ an instrument similar to Card (2001). Their OLS estimates use total changes in skill mix, regardless of nativity. "Permanent" firms are those that exist in both 1985 and 1995.
} 
3. Apparent shifts in "production technique" may be confounded by shifts in product mix, which should be accounted for with care.

To date, though, the evidence seems to say that product mix is very unresponsive to shifts in skill mix, supporting the "single good" modeling simplification.

As a final point, based on the evidence researchers have produced to date, choice of technique models are not necessarily empirically distinguished from models of directed technical change, in which skill mix changes would also lead to attenuated wage responses and to shifts in production technique. On the one hand, one expects that the set of "available" production technologies might be similar across the regions where these models have been tested, which tends to support the choice of technique interpretation. On the other hand, there is some evidence that production innovations do not flow much beyond their region of origin, at least as measured by patent citations (e.g., Jaffe et al. 1993). This is further discussed below.

\section{Historical Studies}

Choice of technique models have much greater and longer acceptance in economic history research. A prominent example is Goldin \& Sokoloff (1984), whose model is very similar to Beaudry \& Green's $(2003,2005)$ but predates it by two decades. ${ }^{39}$ Although they do not study the impact of foreign immigration, they tell a very similar story: industrialization occurred disproportionately in the northern U.S., the authors argue, because unskilled labor - in the form of available female and child labor - was relatively available compared to south, where it was demanded in agriculture.40

\footnotetext{
${ }^{39}$ And before them, Habakkuk (1962) argued that American manufacturing was more standardized because of the high cost of labor in the U.S. Habakkuk's description has also been interpreted as a model of directed technical change. 40 Related to this, Kim (2007) shows using data from the 1850-1880 Censuses that counties with high densities of immigrants were more likely to have had large factories, a proxy for "industrial production." His evidence is, however,
} 
Another advantage of economic history is that publicly accessible historical data on production in the U.S. are sometimes - perhaps surprisingly - richer than equivalent modern public data. Public tabulations of historical Censuses of Manufacturing and Agriculture, for example, are not only rich geographically - going down to the subcounty level in some cases - but contain estimates of capital stock and output mix which are largely unavailable in recent regional tabulations.

Taking advantage of this, for example, are Gonzalez-Velosa et al. (2011) who combine Census of Population and county-level tabulations of the Census of Agriculture between 1900 and 1940 and ask how inflows of immigrants affected agriculture crop mix and production methods. They find some evidence of Rybczynski effects, namely that an immigration-induced increase in farmers per acre of land was associated with a relative decline in wheat production, which they say historians consider a less labor-intensive crop. ${ }^{41}$ On the other hand, they also find an association with decreased cotton production, which is considered labor intensive. They also find this increase was associated with a greater use of mules relative to tractors, and lower capital-labor and capital-land ratios, though the latter is not statistically significant. ${ }^{42}$ This is consistent, they show, with land and capital being q-complements and capital and labor being q-substitutes or neutral. They do not, however, find any evidence that capital complements labor relative to land - capital output ratios are not significantly associated with increases in farmers per acre.

All in all, the historical data seems a largely untapped resource for immigration studies. Although there are limitations - including a lack of individual-level wage data - such research could give new insight into how U.S. labor markets adjusted to the large waves of immigrants of the past two centuries.

largely cross-sectional, and although it does use instruments, many of the instruments seem likely to have some direct impact on the viability of large-scale manufacturing (such as distance to New York, access to waterways).

41 "Immigration-induced" variation refers to their IV estimates, which uses the sort of "ethnic enclave" instrument earlier described.

${ }^{42}$ Similarly, Lew (2010) finds faster adoption of (labor-saving) tractors in the northern great plains of the U.S. relative to a bordering area of Canada following the imposition of drastic U.S. immigration quotas in the mid-1920s. 


\section{Human Capital Spillovers, Innovation, and Productivity}

Moretti (2004a) found that average wages among observably similar workers (and Moretti 2004b that average productivity at observably similar plants) are higher in U.S. metropolitan areas with a greater share of workers who are college educated, which he interpreted as evidence of Marshallian human capital spillovers. In contrast, Sand (2007) has shown, in part using immigration-derived variation, that this positive association is not replicated in more recent data. ${ }^{43}$ Recently, more studies have begun using immigration-derived variation in skill mix to look for evidence for or against spillovers.

Peri (2012) has done so, with surprising results. Using the production framework described in equations (5) and (8), Peri first uses state-level data on output and wages to impute values of "A" total factor productivity (TFP). He then regresses TFP growth on immigration. Even though immigration is associated with a decline in the college share, Peri finds a significant positive, rather than negative association with TFP. One interpretation of this finding is that immigration may have a direct positive effect on TFP, separate from any human capital spillovers, and Peri provides some suggestive evidence that it results partly from task specialization by nativity among less skilled workers. ${ }^{44}$ However, like all growth accounting exercises, Peri's approach is prone to bias from misspecification: Peri constructs TFP using assumed values of production function parameters. However, he is admirably up front about the fact that his estimates are sensitive to

\footnotetext{
43 Acemoglu \& Angrist (2000) (AA) also find no association between average years of schooling and wages. Both AA and Moretti argue that the differences may come partly from the fact that spillovers from education may differ at lower (AA's variation) and higher levels of education. Iranzo \& Peri (2009) confirm this: combining both Moretti's (2004a) and AA's instruments along with an "ethnic enclave" style immigration instrument in a panel of U.S. states, they show that increased years of education among college educated workers is associated with significantly higher average wages, while increased years of education among non-college workers is not.

44 Peri \& Sparber (2009) provide evidence that less-skilled immigrants may have a comparative advantage in "manual" tasks (relative to "communication" tasks) compared to less-skilled natives. When Peri (2012) controls for Peri and Sparber's measure of the manual to communication task ratio, the positive association between TFP and immigration diminishes. As task content is endogenous, this approach is at best suggestive, however.
} 
small changes in the assumed value of the elasticity of substitution, and all of his estimates are positive using values of the elasticity of substitution that are typically found between college and non-college workers.

Another interpretation is that the impact of high skill immigration is not necessarily positive. Borjas \& Doran (2011) find very little sign of spillovers from the influx of mathematicians from the former Soviet Union (FSU) to the U.S. after the fall of the FSU. The response instead resembles standard labor market competition, with U.S. mathematicians in similar fields displaced to lowerranked institutions, where they produced less research. Paserman (2011) investigated impact of the wave of highly skilled FSU immigrants that came to Israel in the 1990s. He finds little evidence that Israeli manufacturing plants or industries with more FSU immigrants were more productive. This may not totally rule out positive spillovers, which may be external even to an industry. Paserman found a positive association between FSU density and productivity in high tech sectors. ${ }^{45}$ Although it has not been considered in any immigration paper that I am aware of, a related idea is that the skill content of the workforce affects growth rates (e.g., Romer 1986, 1990; Lucas 1988).46 This has been largely supported by cross-country correlations (e.g., Barro 1991), which have been challenged as potentially entirely reverse causal (Bils \& Klenow, 2000). Immigration may provide a way to break this endogeneity problem. For example, one could examine whether the spike in former Soviet Union immigration to Israel resulted in a divergence of Israel's growth rate from an appropriately chosen comparison region.

While the possibility of human capital spillovers is interesting, the idea that human capital is just "in the air" (Marshall 1920) is not a very compelling model of the labor market. Research which examines mechanisms, such as Peri's task specialization idea (or see Sand 2007), would be

\footnotetext{
${ }^{45}$ Also, Friedberg (2001) found faster native Israeli wage growth in occupations with greater FSU presence.

${ }^{46}$ Bodvarsson \& Van den Berg (2009) have an extended discussion of the role immigration might play in various theories of economic growth (Chapter 9).
} 
valuable. On this front, new research examines how immigration affects things like patenting an entrepreneurship, which provide potential channels through which immigration might affect productivity or growth. Below, I review some recent findings.

\section{Innovation}

A starting point for the idea that immigration contributes to innovation is the overrepresentation of immigrants -especially Chinese and Indian immigrants in the U.S. - among those who create or work in "high tech" tech firms (e.g., Saxenian 2002) and among high skill workers more generally, especially in technical fields. Brunello et al. (2007) reports that, in the U.S., 20 percent of natural scientists and engineers are foreign born, and 27 percent of percent of Nobel Prize winners in the natural sciences are foreign born.

Recent research associates high skill immigration with increased innovative activity as measured by patents. Two recent studies (Hunt \& Gauthier-Loiselle 2010, hereafter HGL; and Kerr \& Lincoln 2010) show that not only do high-skill immigrants themselves have high rates of patenting, but they may even induce native-born workers to produce more patents. HGL show using the 2003 National Survey of College Graduates (NSCG) that college-educated immigrants have higher patenting rates than college-educated natives, which can be fully accounted for with observed education and field of study (college-educated immigrants are more likely to have graduate degrees and to be scientists and engineers). They then show, using U.S. Patent and Trademark Office (USPTO) data tabulated to the state level and merged to Census data from 1940 - 2000, that an increased state presence of both college-educated immigrants and natives is associated higher patent rates (patents per capita), and that both effects, as well as the immigrant-native gap in effects, are larger than what would be expected "mechanically" from average patenting rates by nativity in the NSCG. The authors interpret this as support for "spillovers" from a presence of highly educated (especially) 
immigrants. ${ }^{47}$ Including spillovers, their IV estimates are consistent with the surge in skilled immigration in the 1990s accounting for at least 20 percent of the aggregate rise in patenting activity during that decade.

HGL compare individual to aggregate patenting rates for evidence of spillovers because USPTO counts are not separated by nativity. In their study of H-1B immigrants, Kerr \& Lincoln (2010) aim to get around this using the fact that most H-1B holders come from India or China. They match inventor names in individual patent records to an ethnic names database, which they use to separate patent counts by Indian, Chinese, Anglo-Saxon, and other ethnicity. They then regress ethnicity x metro area x year patent counts, which cover 1995-2007, on H-1B counts nationally interacted with two measures of what they call local "H-1B dependency": (1) the number of H-1B applications in 2001-2 or (2) the size of the immigrant science and engineering workforce in 1990, both per capita. 48

They find that a 10 percent increase in H-1B's nationally is associated with 3 percent more of both ethnic Indian and Chinese patents for each standard deviation increase in H-1B dependency. They find a weaker association with Anglo-Saxon patenting, which rises 0.1-0.5, and overall patenting, which rises 0.3-0.7 percent.49 The response of Anglo-Saxon patenting is suggestive of "spillovers," though the effects are smaller than in HGL. There are, however, good reasons to expect spillovers would be weaker in the Kerr and Lincoln data: some of the ethnic Indian and especially ethnic Chinese could be native-born; in addition, HGL examine long-differences (10 and 50 year) which

\footnotetext{
47 Using similar data to HGL, Brunello et al. (2007) also estimate U.S. state panel regressions showing that increases in the share of Ph.D.s working in science and engineering is associated with higher patent counts, with a larger effect of foreignborn Ph.D.s, complementing wage evidence that says foreign-born Ph.D.s are on average more skilled. 48 This is necessary because public data on counts of H-1B workers by region over time do not exist.

${ }^{49}$ It is also associated with a 4 percent increase in immigrant science and engineering workforce. According to HGL, a 4 percent increase in immigrant scientists and engineers per capita would result in $0.5 \%$ more patents (calculated by converting the 45.7 coefficient estimate in HGL's Table 9, column 3 to an elasticity by multiplying the mean scientist and engineer share, 0.003 (HGL Table 2), and multiplying by 0.04). While it is interesting that the magnitudes are similar in the two studies, with such large differences in methodology, it is not clear these estimates should be compared.
} 
will capture spillovers that do not occur immediately; HGL generally find bigger effects in longer differences.

To return to the motivation of this section, does the regional association of high-skill immigration with increased patenting matter for the productivity or growth of that region? Other research suggests that it might. First, patent citations seem to fall off quickly in distance, indirectly suggesting that new ideas may have a larger impact on the region of origin than farther away (e.g., Jaffe et al. 1993; Maruseth \& Verspagen 2002; Peri 2005). In addition, there is at least a positive association between patenting rates and productivity and growth (Eaton \& Kortum, 1996; Furman et al. 2002). Indeed HGL use the latter of these two papers to project that the rise in collegeeducated immigration in the 1990s may have increased U.S. GDP per capita by 2 percentage points. Nevertheless, HGL are careful to point out that other high skill workers may contribute more to GDP than scientists and engineers. In addition, studies that link patents to productivity are purely correlational.

A potentially valuable avenue for future research would be to explore more of the content of innovations instead of just the count of innovations. For example, if a metric of the skill content of innovations could be developed, it might be used to help distinguish models of directed technical change from choice of technique models. Such metrics may not be simple to develop, however, which may be why we have not seen such research to date.

\section{Immigrant Entrepreneurship}

Immigrant entrepreneurship may also affect the structure of production. In the U.S., immigrants are 30 percent more likely than natives to start businesses that have at least 10 employees within five years (Hunt 2011), and also make up a disproportionate share of business owners (Fairlie 
2008). Immigrants also are responsible for the creation of many high tech firms in the U.S. (e.g., Saxenian, 2002).

Immigrant businesses play an important role in absorbing immigrant workers into the economy. According to 1992 U.S. matched employer-employee data, 43 percent of immigrants (and only 12 percent of natives) work at immigrant-owned businesses (Garcia-Perez 2008). ${ }^{50}$ Language skills may be a key reason immigrants congregate together: workers with poor English skills are a significantly more concentrated across employers (Andersson et al. 2010; Hellerstein \& Neumark 2003). Other research suggests language skills may also be a key reason for the modest degree of imperfect substitutability between observably similar immigrants and natives (Lewis 2011b). The fact that low-English immigrants are concentrated at immigrant employers is consistent with this: it suggests low-English immigrants operate in a somewhat distinct labor market.

High rates of immigrant entrepreneurship may also matter for productivity growth. Descriptively, firm net entry accounts for a large share of productivity growth, so more "attempts" at starting businesses may lead to higher productivity. ${ }^{51}$ Entrepreneurship rates are also positively correlated with productivity across regions (e.g., van Praag \& Versloot 2007). While further advances in this area will be difficult - employer-employee data are difficult to come by - the role of firms in absorbing immigrant arrivals is an area ripe for further research.

\section{Conclusion}

A variety of new evidence suggests a commonly used rigid production structure with skill-neutral capital is an inadequate framework for the analysis of the labor market impact of immigration.

\footnotetext{
50 They are also 12 percent more productive than native-owned businesses, which may help account for the positive TFP association that Peri (2012) found.

51 For example, net entry accounts for 30 and 100 percent of productivity growth in manufacturing and retail, respectively, over a 10 year period (Haltiwanger 2006).
} 
Allowing for a reasonable level of capital-skill complementarity, for which there is considerable support outside of immigration research, alone lowers the impact of immigration-induced skill mix changes on skilled relative wages by 40 percent relative to simulations that treat capital as neutral. Other models which enjoy some support, including those that feature endogenous choice of technique, directed technical change, and human capital spillovers, also suggest the standard framework may misstate immigration's long run impact on wages. Immigration-derived variation also has untapped potential to improve identification of these alternative models, or to refute them. 


\section{Literature Cited}

Andersson F, Garcia-Perez M, Haltiwanger J, McCue K, Sanders S. 2010. "Workplace Concentration of Immigrants." NBER Working Paper \#16544

Acemoglu D. 1998. "Why Do New Technologies Complement Skills? Directed Technical Change and Wage Inequality." The Quarterly Journal of Economics 113(4): 1055-89

Acemoglu D. 2002. “Technical Change, Inequality and the Labor Market.” Journal of Economic Literature 40(1): 7-72

Altonji JG, Card D. 1991. "The Effects of Immigration on the Labor Market Outcomes of Less-Skilled Natives." In John M. Abowd and Richard B. Freeman, eds., Immigration, Trade, and the Labor Market. Chicago: University of Chicago Press, 201-34

Acemoglu D, Angrist J. 2000. "How large are human capital externalities? Evidence from Compulsory Schooling Laws.” NBER Macroeconomics Annual

Autor DH, Levy F, Murnane RJ. 2003. "The Skill Content of Recent Technological Change: An Empirical Exploration," The Quarterly Journal of Economics 118(4): 1279-1334

Autor DH, Katz LF, Krueger A. 1998. “Computing Inequality: Have Computers Changed the Labor Market?” The Quarterly Journal of Economics 113(4): 1169-1214

Autor DH, Katz LF, Kearney MS. 2006. "The Polarization of the U.S. Labor Market.” The American Economic Review 96(2): 189-194

--- . 2008. "Trends in U.S. Wage Inequality: Revising the Revisionists.” The Review of Economics and Statistics $90(2): 300-323$

Barcellos SH. 2010. “The Dynamics of Immigration and Wages.” RAND Working Paper \#WR-755

Barro RJ. 1991. "Economic Growth in a Cross Section of Countries." Quarterly Journal of Economics 106(2): 407-43

Beaudry P, Doms M, Lewis E. 2010. "Should the PC be Considered a Technological Revolution? Evidence from US Metropolitan Areas." Journal of Political Economy 118(5): 988-1036

Beaudry P, Green DA. 2003. "Wages and Employment in the United States and Germany: What Explains the Differences?" The American Economic Review 93(3): 573-602

Beaudry P, Green DA. 2005. “Changes in U.S. Wages, 1976-2000: Ongoing Skill Bias or Major Technological Change?” Journal of Labor Economics 23(3): 609-648

Bils M, Klenow P. 2000. “Does Schooling Cause Growth?” American Economic Review 90(5): 11601183

Bodvarsson OB, Van Den Berg H. 2009. The Economics of Immigration: Theory and Policy. Heidelberg, Germany: Springer-Verlag

Borjas GJ. 1987. "Immigrants, Minorities, and Labor Market Competition.” Industrial and Labor Relations Review 40(3): 382-392

Borjas GJ. 1994. “The Economics of Immigration.” Journal of Economic Literature 32(4): 1667-1717.

Borjas GJ. 2003. "The Labor Demand Curve is Downward Sloping: Reexamining the Impact of Immigration on the Labor Market." The Quarterly Journal of Economics 118(4): 1335-1374

Borjas GJ. 2006. "Native Internal Migration and the Labor Market Impact of Immigration." Journal of Human Resources 41(2): 221-257 
Borjas GJ. 2009. “The Analytics of the Wage Effect of Immigration.” Mimeo, Harvard University

Borjas GJ, Doran KB. 2011. "The Collapse of the Soviet Union and the Productivity of American Mathematicians." Mimeo, Harvard University

Borjas, George J., Richard B. Freeman and Lawrence F. Katz. 1997. "How Much Do Immigration and Trade Affect Labor Market Outcomes?” Brookings Papers on Economic Activity 1997(1): 1-90

Borjas GJ, Grogger J, Hanson GH. 2008. "Imperfect Substitution Between Immigrants and Natives: A Reappraisal.” NBER Working Paper \#13887

Borjas GJ, Katz LF. 2007. "The Evolution of the Mexican-Born Workforce in the United States" in Borjas GJ, ed., Mexican Immigration to the United States. Chicago: University of Chicago Press, 13-26

Brunello G, Fredriksson P, Lamo A, Messina J, Peri G. 2007. "Higher Education, Innovation and Growth" in Brunello G, Garibaldi P, Wasmer E, eds., Education and Training in Europe. New York: Oxford University Press, 56-70 (Chapter 3)

Card D. 1990. "The Impact of the Mariel Boatlift on the Miami Labor Market." Industrial and Labor Relations Review 43(2): 245-257

Card D. 2001. "Immigrant Inflows, Native Outflows, and the Local Labor Market Impacts of Higher Immigration." Journal of Labor Economics 19(1): 22-64

Card D. 2009. "Immigration and Inequality," The American Economic Review 99(2): 1-21

Card D, Lewis E. 2007. “The Diffusion of Mexican Immigrants During the 1990s: Explanations and Impacts" in Borjas, George J., ed., Mexican Immigrant to the United States. Chicago and London: The University of Chicago Press, 193-228

Caselli F. 1999. “Technological Revolutions,” The American Economic Review, 89(1): 78-102

Caselli F, Coleman II WJ. 2006. "The World Technology Frontier.” American Economic Review 96(3): 499-522

Ciccone A, Peri G. 2011. "Schooling Supply and the Structure of Production: Evidence from US States, 1950-1990.” NBER Working Paper \#17683

Cortes P. 2008. "The Effect of Low-Skilled Immigration on US Prices: Evidence from CPI Data." Journal of Political Economy 116(3): 381-422

Cohen-Goldner, Sarit, and M. Daniele Paserman. 2011. "The Dynamic Impact of Immigration on Natives' Labor Market Outcomes: Evidence From Israel." European Economic Review 55(8): 1027-1045

Docquier F, Ozden C, Peri G. 2010. “The Wage Effects of Immigration and Emigration.” NBER Working Paper \#16646

Dustmann C, Glitz A. 2012. "How Do Industries and Firms Respond to Changes in Local Labor Supply?" Mimeo, University College London.

Doms M, Lewis E. 2006. “Labor Supply and Personal Computer Adoption.” Federal Reserve Bank of San Francisco Working Paper \#2006-18

Eaton J, Kortum S. 1996. "Trade in Ideas: Patenting and Productivity in the OECD." Journal of International Economics 40(1/2): 251, 278

Ethier WJ. 1972. "Nontraded Goods and the Heckscher-Ohlin Model." International Economic Review 13(1): $132-147$ 
Friedberg RM. 2001. "The Impact of Mass Migration on the Israeli Labor Market.” The Quarterly Journal of Economics 116(4): 1373-1408.

Friedberg RM, Hunt J. 1995. "The Impact of Immigrants on Host Country Wages, Employment, and Growth." Journal of Economic Perspectives 9(2): 23-44

Furman JL, Porter ME, Stern S. 2002. "The Determinants of National Innovative Capacity.” Research Policy 31(6): 899-933

Garcia-Perez M. 2008. "Does it Matter Who I Work For and Who I Work With? The Impact of Owners and Coworkers on Hiring and Wages." Mimeo, University of Maryland

Goldin C, Katz LF. 1998. “The Origins of Technology-Skill Complementarity.” The Quarterly Journal of Economics 113(3): 693-732

Goldin C, Katz LF. 2008. The Race Between Education and Technology, Cambridge, MA: Harvard University Press

Goldin C, Sokoloff K. 1984. "The Relative Productivity Hypothesis of Industrialization: The American Case, 1820 to 1850." The Quarterly Journal of Economics 99(3): 461-487

Gonzales L, Ortega F. 2011. "How Do Very Open Economies Absorb Large Immigration Flows? Recent Evidence from Spanish Regions." Labour Economics 18(1): 57-70

Gonzalez-Velosa C, LaFortune J, Tessada J. 2011. "More Hands, More Power? The Impact of Immigration on Farming and Technology Choices in US Agriculture in the Early Twentieth Century." Mimeo, University of Maryland

Griliches Z. 1969. “Capital-Skill Complementarity.” The Review of Economics and Statistics 51(4): 465-468

Grossman JB. 1982. "The Substitutability of Natives and Immigrants in Production.” The Review of Economics and Statistics 64(4): 596-603

Habakkuk HJ. 1962. American and British Technology in the Nineteenth Century: The Search for Labor-Saving Inventions. London: Cambridge University Press

Hamermesh DS. 1993. Labor Demand. Princeton, NJ: Princeton University Press

Hanson GH. "The Economic Consequences of the International Migration of Labor." Annual Review of Economics 2009(1): September 2009, pp. 179-207

Hanson GH, Slaughter MJ. 2002. "Labor-Market Adjustments in Open Economies: Evidence from US States." Journal of International Economics 57(1): 3-29

Hellerstein J, Neumark D. 2003. "Ethnicity, Language and Workplace Segregation: Evidence from a New Matched Employer-Employee Dataset." Annals of Economics and Statistics 71/72: 1978

Hunt J. 2011. "Which Immigrants are Most Innovative and Entrepreneurial? Distinctions by Entry Visa." Journal of Labor Economics 29(3): 417-457

Hunt J, Gauthier-Loiselle M. 2010. "How Much Does Immigration Boost Innovation?” American Economic Journal: Macroeconomics 2: 31-56

Iranzo S, Peri G. 2009. "Schooling Externalities, Technology, and Productivity: Theory and Evidence from U.S. States." Review of Economics and Statistics 91(2): 420-431

Jaffe AB, Trajtenberg MJ, Henderson R. 1993. “Geographic Localization of Knowledge Spillovers as Evidenced by Patent Citations." The Quarterly Journal of Economics 108 (3): 577-598 
Katz LF, Murphy KM. 1992. "Changes in Relative Wages, 1963-1987: Supply and Demand Factors." The Quarterly Journal of Economics 107(1): 35-78

Kerr W, Lincoln WF. 2010. "The Supply Side of Innovation: H-1B Visa Reforms and U.S. Ethnic Invention." Journal of Labor Economics 28(3): 473-508

Kim S. 2007. "Immigration, Industrial Revolution and Urban Growth in the United States, 18201920: Factor Endowments, Technology and Geography." NBER Working Paper \#12900

Krueger A. 1993. "How Computers Have Changed the Wage Structure: Evidence from Microdata 1984-1989.” The Quarterly Journal of Economics 108(1): 33-60

Krusell, Per, Lee E. Ohanian, Jose-Victor Rios-Rull, and Giovanni L. Violante. 2000. "Capital-Skill Complementarity and Inequality: A Macroeconomic Analysis," Econometrica 68(5): 10291053

Kugler A, Yuksel M. 2008. "The Impact of Less Skilled Immigration on U.S. Natives: Evidence from Hurricane Mitch." NBER Working Paper \#14293

Leamer EE. 1995. “The Heckscher-Ohlin Model in Theory and Practice.” Princeton Studies in International Finance 77. Princeton, NJ: International Finance Section

Lew B, Cater B. 2010. "Farm Mechanization on an Otherwise 'Featureless' Plain: Tractors on the Norther Great Plains and Immigration Policy of the 1920s."

Lewis E. 2003. “Local, Open Economies Within the U.S.: How Do Industries Respond to Immigration?" Federal Reserve Bank of Philadelphia Working Paper \#04-01

Lewis E. 2004. "How Did the Miami Labor Market Absorb the Mariel Immigrants?" Federal Reserve Bank of Philadelphia Working Paper \#04-03

Lewis E. 2011a. "Immigration, Skill Mix, and Capital-Skill Complementarity." Quarterly Journal of Economics 126(2): 1029-1069

Lewis E. 2011b. "Immigrant-Native Substitutability: The Role of Language Ability.” NBER Working Paper \#17609

Longhi S, Nijkamp P, Poot J. 2005. "A Meta-Analytic Assessment of the Effect of Immigration on Wages." Journal of Economic Surveys 19(3): 451-477

Longhi S, Nijkamp P, Poot J. 2008. "A Meta-Analysis of Empirical Evidence on the Labour Market Impacts of Immigration." Region et Developpement 27: 161-191

Marshall A. 1920. Principles of Economics. London: Macmillan and Co., Ltd. Accessed online at Library of Economics and Liberty at http://www.econlib.org/library/Marshall/marP.html on 22 June 2012

Maurseth P, Verspagen B. 2002. "Knowledge Spillovers in Europe: A Patent Citations Analysis." Scandinavian Journal of Economics 104(4): 531-545

Moretti E. 2004a. "Estimating the Social Return to Higher Education: Evidence from Longitudinal and Repeated Cross-Sectional Data." Journal of Econometrics 121(1): 175-212

Moretti E. 2004b. “Workers' Education, Spillovers and Productivity: Evidence from Plant-Level Production Functions." American Economic Review 94(3): 656-690

Ottaviano G, Peri G. 2006. "Rethinking the Effect of Immigration on Wages." National Bureau of Economic Research Working Paper \#12497 
Ottaviano G, Peri G. 2012. "Rethinking the Effect of Immigration on Wages." Journal of European Economic Association 10(1): 152-197

Paserman DM. 2011. “Do High-Skill Immigrants Raise Productivity? Evidence from Israeli Manufacturing Firms, 1990-1999." Mimeo, Boston University

Peri G. 2005. “Determinants of Knowledge Flows and Their Effect on Innovation.” Review of Economics and Statistics 87(2): 308-322

Peri G. 2011. "The Impact of Immigration on Native Poverty Through Labor Market Competition." NBER Working Paper \# 17570

Peri G. 2012. "The Effect of Immigration on Productivity: Evidence from U.S. States.” Review of Economics and Statistics 94(1): 348-358

Peri G, Sparber CS. 2009. “Task Specialization, Immigration, and Wages.” American Economic Journal: Applied Economics 1(3): 135-69

Peri G, Sparber CS. 2011. "Assessing Inherent Model Bias: An Application to Native Displacement in Response to Immigration." Journal of Urban Economics 69(1): 82-91

Sand, B. 2007. "Has There Been a Structural Change in the Labor Market? Evidence from U.S. Cities." Mimeo, University of British Columbia.

Saxenian A. 2002. "Silicon Valley's New Immigrant High Growth Entrepreneurs.” Economic Development Quarterly 16(1): 20-31

Schott PK. 2004. "Across-Product versus Within-Product Specialization in International Trade." Quarterly Journal of Economics 119(2): 647-678

Stokey NL. 1996. "Free Trade, Factor Returns, and Factor Accumulation." Journal of Economic Growth 1(4): 421-447

Van Praag CM, Versloot PH. 2007. "What is the Value of Entrepreneurship? A Review of Recent Research.” Small Business Economics 29: 351-382

Wozniak A, Murray TJ. 2012. "Timing is Everything: Short-Run Population Impacts of Immigration in U.S. Cities." Journal of Urban Economics 72(1): 60-72 
Table 1. 1990-2000 Immigrant Net Arrivals/Existing Labor Force, by Country and Broad Education

\begin{tabular}{|c|c|c|c|c|}
\hline \multirow[b]{2}{*}{ Country } & \multicolumn{2}{|c|}{ Broad Education } & \multirow{2}{*}{$\begin{array}{l}\text { Diff (2)-(1): } \\
\approx \% \text { Impact on } \\
\text { Skill Ratio }\end{array}$} & \multirow{2}{*}{$\begin{array}{l}\approx \% \Delta \text { in Coll Rel. } \\
\text { Wage in "Stan- } \\
\text { dard Model" }\end{array}$} \\
\hline & $\begin{array}{c}\text { Less than } \\
\text { College }\end{array}$ & $\begin{array}{c}\text { College or } \\
\text { More }\end{array}$ & & \\
\hline & (1) & $(2)$ & (3) & (4) \\
\hline United States & 6.2 & 4.6 & -1.6 & 1.0 \\
\hline Italy & 0.9 & 0.8 & -0.1 & 0.1 \\
\hline Greece & 0.2 & 0.2 & 0.0 & 0.0 \\
\hline Portugal & 1.3 & 1.9 & 0.6 & -0.4 \\
\hline Germany & 2.2 & 3.2 & 0.9 & -0.6 \\
\hline Spain & 2.8 & 4.0 & 1.2 & -0.8 \\
\hline France & 0.1 & 2.9 & 2.8 & -1.9 \\
\hline Belgium & 1.7 & 4.6 & 2.9 & -1.9 \\
\hline Sweden & 1.5 & 5.4 & 3.9 & -2.6 \\
\hline Netherlands & 1.3 & 5.4 & 4.1 & -2.7 \\
\hline Canada & 0.8 & 8.7 & 7.9 & -5.3 \\
\hline United Kingdom & 0.4 & 9.3 & 8.9 & -5.9 \\
\hline Australia & -0.6 & 11.9 & 12.5 & -8.3 \\
\hline
\end{tabular}

Data Source: Docquier, Ozden, and Peri (2010), Table 1. Their table showed i = immigrants/ (immigrants + existing labor force); the numbers in the table above are transformed to immigrants/existing workforce, that is, $i /(1-i) .{ }^{a}$ Column $(4)=-2 / 3^{*}$ column (3), i.e., the estimated impact of immigration on college - non-college log wage gap, assuming an elasticity of substitution between college and non-college of 1.5 . 
Table 2. Simulated Relative Wage Impact of a One Percentage Point Increase in the Skill Ratio, Alternative Production Functions

\begin{tabular}{|c|c|c|c|c|}
\hline \multirow[t]{2}{*}{ Description/Source } & \multicolumn{3}{|c|}{ Parameter Values } & \multirow{2}{*}{$\begin{array}{c}\text { \%Impact } \\
\text { on Rel. Wage } \\
\end{array}$} \\
\hline & $\delta$ & SS & $\mathrm{s}_{\mathrm{K}}$ & \\
\hline & \multicolumn{4}{|c|}{$\mu=0$ (Cobb-Douglass) $\rightarrow s_{S}=1-\alpha$} \\
\hline (1) Benchmark: Neutral Capital & 0.00 & $\in(0,1)$ & $\in(0,1)$ & -1.00 \\
\hline (2) Stokey (1996) ${ }^{b}$ & 0.50 & 0.62 & 0.30 & -0.59 \\
\hline (3) Lewis (2011a) ${ }^{c}$ est of $\partial \operatorname{lns}_{K} / \partial(U / S)$ & 0.53 & 0.72 & 0.20 & -0.58 \\
\hline (4) variant of (2) & 0.30 & 0.62 & 0.30 & -0.77 \\
\hline (5) variant of (2) & 0.70 & 0.62 & 0.30 & -0.38 \\
\hline \multirow[t]{2}{*}{ (6) Autor, Levy, Murnane (2003) } & 1.00 & $\in(0,1)$ & $\in(0,1)$ & 0.00 \\
\hline & \multicolumn{4}{|c|}{$\mu=0.33$} \\
\hline (7) Benchmark: Neutral Capital & 0.33 & $\in(0,1)$ & $\in(0,1)$ & -0.67 \\
\hline (8) Lewis (2011a) ${ }^{3}$ est of $\partial \operatorname{lns}_{K} / \partial(U / S)$ & 0.68 & 0.72 & 0.20 & -0.39 \\
\hline (9) Variant of (2) & 0.50 & 0.62 & 0.30 & -0.54 \\
\hline (10) Variant of (6) & 1.00 & $\in(0,1)$ & $\in(0,1)$ & 0.00 \\
\hline
\end{tabular}

${ }^{a}$ Simulated impact of a one percentage point increase in $\ln (\mathrm{S} / \mathrm{U})$, where "S" represents skilled and "U" unskilled labor, on the skilled-unskilled log wage gap in a competitive single-good economy represented by the production function $Q=\left[\alpha\left(U^{\delta}+K^{\delta}\right)^{(\mu / \delta)}+(1-\alpha) S^{\mu}\right]^{1 / \mu}$, where $K$ represent capital. This impact is approximated as $(\delta-\mu)(1-\mu) s_{S} s_{K} /\left[(\delta-\mu) s_{K} S_{S}+(1-\delta)(1-\right.$ $\left.\left.s_{S}\right)\left(1-s_{K}\right)\right]+\mu-1$, where $s_{K}$ represents capital's share and $s_{S}$ skilled labor's share of output. ${ }^{b}$ Stokey assumed $\mu=0, \sigma=0.5$ and $\alpha=0.38$ but made no assumption about $s_{K}$. ${ }^{C}$ Lewis estimated $\partial \operatorname{lns}_{K} / \partial(U / S)=-0.56$, (with $U, S$ high school dropouts and completers, respectively) which evaluted at the mean U/S of 0.3 converts to an elasticity of 0.168 . This is converted to an estimate of $\delta$ (for the given value of $s_{S}$ and $s_{K}$ ) using the fact that $\partial \ln s_{K} / \partial \ln (S / U) \approx(\delta-\mu)\left(1-s_{S}-s_{K}\right) s_{S} /\left[(\delta-\mu) s_{K} s_{S}+(1-\delta)\left(1-s_{S}\right)(1-\right.$ $\left.s_{K}\right)$ ]. In that study "capital" represents equipment only, which is why $s_{K}$ is smaller and $s_{S}$ is larger than in other rows. 
Figure 1. Two-Sector Model

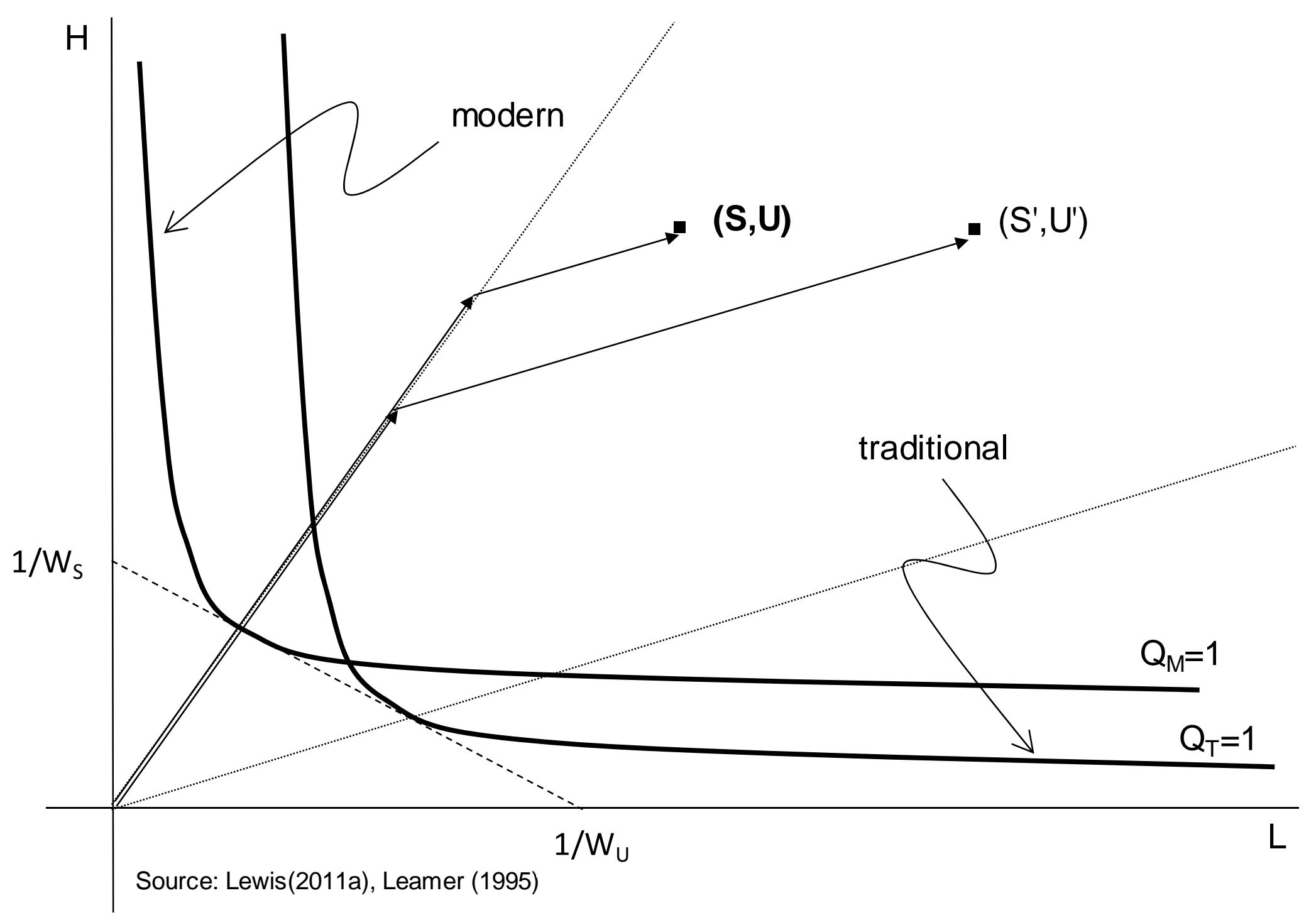


Appendix: Analysis of Capital-Skill Complementarity in a General Production Framework. ${ }^{52}$

Let $\mathrm{K}$ represent capital, S skilled labor, and $\mathrm{U}$ unskilled labor, and let $g(K, S, U)$ be a homogenous, twice continuously differentiable production function representing the entire economy that satisfies $g_{i}>0$ and $g_{i i}<0 \forall i$. The function $g$ is also assumed to exhibit capital-skill complementarity, defined as $\partial \ln \frac{W^{S}}{W^{U}} / \partial \ln K>0$, or, equivalently, since wages are determined in a competitive equilibrium, as

$$
\frac{g_{K S}}{g_{S}}-\frac{g_{K U}}{g_{U}}>0
$$

Multiplying through this expression by $Q / g_{K}$, where $Q=g(K, S, U)$, restates the definition in terms of "elasticities of complementarity." For two factors $X_{i}$ and $X_{j}$ with corresponding prices $w_{i}$ and $w_{j}$, the elasticity of complementarity is $c_{i j}=\frac{\partial \ln \left(w_{i} / w_{j}\right)}{\partial \ln \left(X_{j} / X_{i}\right)}=\frac{Q g_{i j}}{g_{i} g_{j}}$ (Hamermesh, 1993), i.e., the response of relative wages to relative factor employment. Thus, complementarity is equivalently defined as $c_{K S}>c_{K U}$. In (3), for example, $c_{K S}=1-\mu$ and $c_{K U}=1-\delta$, so complementarity requires $\delta>\mu$.

Consider the long run equilibrium in which $g_{K}=r$, where $\mathrm{r}$ is the exogenously determined rental rate of capital. Totally differentiating this expression, we have that $K g_{K K} d \ln K+S g_{K S} d \ln S+$ $U g_{K U} d \ln U=0$. Combined with the homogeneity identity $K g_{K K}+S g_{K S}+U g_{K U}=0$, this can be solved for $d \ln K$ :

(9) $d \ln K=\frac{S g_{K S}}{S g_{K S}+U g_{K U}} d \ln S+\frac{U g_{K U}}{S g_{K S}+U g_{K U}} d \ln U$

Note that the denominator is positive, since $S g_{K S}+U g_{K U}=-K g_{K K}>0$. Next, again from homogeneity:

$$
d \ln Q=s_{K} d \ln K+s_{S} d \ln S+\left(1-s_{K}-s_{S}\right) d \ln U
$$

where $s_{K}$ and $s_{S}$ are capital and skilled labor's shares of output, respectively, for example, $s_{K}=\frac{r K}{Q}$. Differencing $d \ln K$ from (10), substituting in (9), and rearranging, we arrive at: 53

52 This section is adapted from Gonzales-Velosa, LaFortune, and Tessada (2011).

${ }^{53} d \ln _{K}=d \ln r+d \ln K-d \ln Q=d \ln K-d \ln Q$. 


$$
d \ln s_{K}=Q \frac{\left(1-s_{S}-s_{K}\right) s_{S}\left(\frac{g_{K S}}{g_{S}}-\frac{g_{K U}}{g_{U}}\right)}{S g_{K S}+U g_{K U}}(d \ln S-d \ln U)
$$

So since $\frac{g_{K S}}{g_{s}}-\frac{g_{K U}}{g_{U}}$ is positive by capital-skill complementarity, capital's share is rising in S/U. (11) also implies that if capital's share is rising in S/U, capital and skill are complements.

Using similar substitutions of homogeneity-derived identities, one can show that the long-run response of relative wages satisfies

$$
\left.\frac{\partial \ln \left(W^{S} / W^{U}\right)}{\partial \ln (S / U)}\right|_{d \ln r=0}=-c_{S U}+\left(\frac{g_{K S}}{g_{S}}-\frac{g_{K U}}{g_{U}}\right)\left(-\frac{S g_{K S}}{g_{K K}}\right)
$$

where $c_{S U}$ is the short-run elasticity of complementarity and $-\frac{S g_{K S}}{g_{K K}}>0$ under capital-skill complementarity, so the long-run response is smaller in magnitude than the short-run response. ${ }^{54}$

54 If $g_{K U}>0$, by complementarity $g_{K S}>0$. If $g_{K U} \leq 0$, then $g_{K S}>0$ since $S g_{K S}+U g_{K U}=-K g_{K K}>0$. 